\title{
Aromatase gene and its effects on growth, reproductive and maternal ability traits in a multibreed sheep population from Brazil
}

\author{
Ana Maria Bezerra Oliveira Lôbo ${ }^{1}$, Raimundo Nonato Braga Lôbo ${ }^{1,2}$ and Samuel Rezende Paiva ${ }^{3}$ \\ ${ }^{1}$ Departamento de Zootecnia, Universidade Federal do Ceará, Fortaleza, CE, Brazil. \\ ${ }^{2}$ Embrapa Caprinos e Ovinos, Sobral, Ceará, Brazil. \\ ${ }^{3}$ Embrapa Recursos Genéticos e Biotecnologia, Brasília, DF, Brazil.
}

\begin{abstract}
We determined the polymorphism C242T of the aromatase gene (Cyp19) and its allelic frequency, as well as the effect of the variants on productive and reproductive traits in 71 purebred Santa Inês sheep, 13 purebred Brazilian Somali sheep, nine purebred Poll Dorset sheep, and 18 crossbred 1/2 Dorper sheep. The animals were genotyped using the PCR-RFLP technique. The influence of the animal's genotype on its performance or on the performance of its lambs was analyzed by the least square method. Another factor assessed was the importance of the animal's genotype in analysis models for quantitative breeding value estimates, and whether there were differences among the averages of breeding values of animals with different genotypes for this gene. In the sample studied, no AA individuals were observed; the $A B$ and $B B$ frequencies were 0.64 and 0.36, respectively. All Brazilian Somali sheep were of genotype BB. All 1/2 Dorper BB animals presented a lower age at first lambing, and the Santa Inês BB ewes presented a lower lambing interval. In these same genetic groups, $A B$ ewes presented higher litter weight at weaning. This is evidence that $B B$ ewes have a better reproductive performance phenotype, whereas $A B$ ewes present a better maternal ability phenotype. However, in general, animals with genotype $A B$ presented better average breeding values than those with genotype $\mathrm{BB}$.
\end{abstract}

Key words: body weight, lambing interval, PCR-RFLP, polymorphism, SNP, litter weight.

Received: July 29, 2008; Accepted: February 17, 2009.

\section{Introduction}

The aromatase cytochrome $\mathrm{P} 450$ enzyme is responsible for estrogen biosynthesis by conversion or aromatization of androgens into estrogens. Estrogen is a hormone with important endocrine, paracrine and autocrine activities, involved not only in the regulation of male and female reproduction, but also in other characteristics, such as fat deposition (Heine et al., 2000; Jones et al., 2000) and growth (Simpson et al., 2000).

In the granulosa cells, aromatase is essential for folliculogenesis and, consequently, for oocyte quality. Aromatase is also related, through the aromatization of androgens into estrogens, with the estrus stimulus and the development of the mammary glands. In the ovarian follicles, the theca produces androgens that accumulate when the estrogen synthesis by the granulosa cells is inadequate. This accumulation seems to promote an inhibitory effect on the follicular structures, and consequently, the follicles become atretic and die. In many species, estrogen biosynthesis in the brain has been correlated to sexual behavior,

Send correspondence to Raimundo Nonato Braga Lôbo. Embrapa Caprinos e Ovinos, Estrada Sobral Groaíras km 4, Caixa Postal 145, 62011-970 Sobral, CE, Brazil. E-mail: lobo@ cnpc.embrapa.br. such as mating responses and frequently a pronounced dimorphism between males and females (Simpson et al., 1994).

Some studies performed in cattle have indicated that the estrogens play an important role in the maintenance of pregnancy (Wendorf et al., 1983) and in the beginning of parturition (Hoffmann et al., 1979; Thorburn and Challis, 1979). Estrogen synthesis begins with the mitochondrial cholesterol and androgen substrates, such as androstenedione, that are turned into estrogens by the enzyme aromatase (Conley and Hinshelwood, 2001).

The gene Cyp19 that codifies the aromatase P450 enzyme in sheep has been mapped to bands q24-q31 of chromosome 7 (Payen et al., 1995; Goldammer et al., 1999). In exon 3, which is located in codon 69 , a silent $\mathrm{C} / \mathrm{T}$ transition was detected in several animals (Vanselow et al., 1999). In sheep, Cyp 19 is transcribed from four different promoters (P1.1, P1.4, P1.5 and P2) that present organ-specific activities. P2 is mainly active in granulosa cells, P1.5 and P1.1 are active in the placenta, and P1.4 is active in the brain (Vanselow et al., 1999; 2001).

Studies in humans have shown that a mutation in gene Cyp19 seems to be associated with bone maturation and consequently with linear growth (Morishima et al., 1995; 
Carani et al., 1997). These studies established that estrogen, and not androgen, is responsible for the progress of bone maturation.

The aim of this study was to determine the presence and the allelic frequency of polymorphism C242T (AJ012153) in the aromatase gene in a multibreed sheep population from Brazil. In addition, the effects of the variants on growth, reproductive and maternal ability traits were assessed. The importance of the knowledge of the animal's genotype in the analysis models for estimating the quantitative breeding values of studied traits, and the existence of differences among the averages of these breeding values in animals with different genotypes for this gene were also evaluated.

\section{Materials and Methods}

\section{Blood samples}

For DNA analysis, blood samples were collected from 71 purebred Santa Inês sheep (eight males and 63 females), 13 purebred Brazilian Somali sheep (all females), nine purebred Poll Dorset sheep (two males and seven females), and 18 crossbred 1/2 Dorper sheep (all females). These animals, 10 rams and 101 ewes, were raised in a herd (Gaasa Agropecuária Ltda.) located in Inhumas, Goiás, Brazil, under semi-intensive conditions. This herd is controlled by the Breeding Program for Meat Goats and Sheep (Programa de Melhoramento Genético de Caprinos e Ovinos de Corte - GENECOC), of Embrapa (Brazilian Agricultural Research Corporation) Caprinos e Ovinos.

\section{Genotyping}

DNA was extracted using the salting out protocol (Miller et al., 1988). The PCR-RFLP technique was used to determine the presence and the allelic frequency of the C242T (AJ012153) polymorphism in the Cyp19 gene (aromatase). A $140 \mathrm{bp}$ fragment of the gene was amplified using the primers described by Vanselow et al. (1999), in agreement with the sequence deposited in GenBank (AJ012153): primer 1-5' - CCA GCT ACT TTC TGG GAA TT - 3'; primer 2-5' - AAT AAG GGT TTC CTC TCC ACA - 3'. The polymorphism was determined by endonuclease digestion of the amplified fragment with the Bsp143I enzyme (isochizomer DpnII).

The PCR amplification reaction was carried out in an Eppendorf thermocycler, in a final reaction volume of $25 \mu \mathrm{L}$; each reaction contained 5 pmol of each primer, $1.5 \mathrm{U}$ Taq DNA polymerase (Phoneutria), $100 \mu \mathrm{M}$ of each $\mathrm{dNTP}, 2.5 \mathrm{mM} \mathrm{MgCl}$, $1 \mathrm{X}$ buffer, and 25, 50 or $100 \mathrm{ng}$ ovine genomic DNA, depending on the sample. The amplification program consisted of an initial denaturation step (94 ${ }^{\circ} \mathrm{C}$ for $\left.2 \mathrm{~min}\right), 35$ denaturation $\left(94^{\circ} \mathrm{C}\right.$ for $\left.15 \mathrm{~s}\right)$, annealing $\left(55^{\circ} \mathrm{C}\right.$ for $\left.30 \mathrm{~s}\right)$ and elongation $\left(70^{\circ} \mathrm{C}\right.$ for $\left.2 \mathrm{~min}\right)$ cycles, followed by a final elongation step $\left(70^{\circ} \mathrm{C}\right.$ for $\left.5 \mathrm{~min}\right)$. The amplified products were submitted to electrophoresis on
4\% agarose gels and visualized under an UV transilluminator, after staining with ethidium bromide.

A $10 \mu \mathrm{L}$ aliquot of PCR products was digested in a total volume of $20 \mu \mathrm{L}$ with $5 \mathrm{U}$ of DpnII (Biolabs) and $1 \mathrm{X}$ buffer for $14 \mathrm{~h}$ at $37^{\circ} \mathrm{C}$, followed by inactivation for $20 \mathrm{~min}$ at $65{ }^{\circ} \mathrm{C}$. The digestion products were also electrophoresed on $4 \%$ agarose gel and visualized by ethidium bromide staining.

\section{Statistical analyses}

In order to determine the influence of the genotype of the animal on its performance or on the performance of its lambs (lambs of the 101 ewes), statistical analyses were made using the least square method of the GLM procedure of the SAS software (SAS Institute Inc., 1996). The genetic groups of the lambs tested were: Santa Inês (of Santa Inês ewes), 3/4 Santa Inês (of 1/2 Santa Inês ewes), 3/4 Dorper (of 1/2 Dorper ewes), and 7/8 Dorper (of 3/4 Dorper ewes). The growth traits analyzed were: birth weight (BW), weaning weight (WW), slaughter weight (SW), yearling weight (YW), weight gain from birth to weaning (GBW), weight gain from weaning to slaughter (GWS), and weight gain from weaning to yearling (GWY). These traits were evaluated in all animals (lambs and ewes). In ewes, the reproductive and maternal traits analyzed were: age at first lambing (AFL), lambing interval (LI), gestation length (GL), lambing date (LD; number of days between the beginning of the breeding season and the lambing), litter weight at birth (LWB), and litter weight at weaning (LWW).

Body weights and weight gains were adjusted for season and year of birth, sex (in the case of lamb performance), and birth type (single, twin, triple). BW, WW and GBW were adjusted for age classes ( 1 to 6 ) of the dam at lambing. WW, SW and YW were adjusted for age at measurement as covariate. These weight gains were also adjusted for the respective ages. AFL was adjusted for season and year of birth, animal birth type and lambing type (one male lamb, one female lamb, two male lambs, two female lambs, one male and one female lamb, three lambs regardless of sex). LI, LD, GL, LWB and LWW were adjusted for season and year of birth, lactation number and lambing type (as described above). LWW was also adjusted for the age at weaning as covariate.

Breeding values of the studied traits were estimated by the Derivative-Free Restricted Maximum Likelihood method (DFREML), using the MTDFREML software (Boldman et al., 1995), with an animal model. The analyses were made including the animal genotype as fixed effect or not. These analyses were performed in two ways: either considering the trait measured in the genotyped animal, or considering it in the lambs of the genotyped ewe. The Likelihood Rate (LR) test (Rao, 1973) was used to determine whether models with genotype information were better than those without. LR was estimated as $\mathrm{Lj} / \mathrm{Li}$, where $\mathrm{Lj}$ was the restricted likelihood maximum for models without 
genotype information, and $\mathrm{Li}$ was the restricted likelihood maximum for models with genotype information. The -2 Log LR value was compared to the $\chi^{2}$ tabulated value, with one degree of freedom; the test was considered significant whenever the calculated value was higher than the tabulated value.

Finally, the differences among breeding values of the genotyped animals were determined by variance analysis.

\section{Results}

The PCR digestion products of 111 samples revealed only two genotypes for the Cyp 19 polymorphism: $\mathrm{AB}$ and BB. Genotype AB presents three fragments, of 140, 82 and $58 \mathrm{bp}$, respectively, whereas genotype BB presents only one fragment, of $140 \mathrm{bp}$. Figure 1 presents a sample of 13 genotyped animals.

The frequencies of genotypes $\mathrm{AB}$ and $\mathrm{BB}$ were $0.64 \mathrm{e}$ 0.36 , respectively. Table 1 shows the frequencies for alleles $\mathrm{A}$ and $\mathrm{B}$, according to the genetic groups analyzed.

Table 2 presents the averages of the traits measured in the animals genotyped for gene Cyp19. Data on performance were available only for the animals of the $1 / 2$ Dorper and Santa Inês genetic groups. No difference was observed regarding weight or weight gain among animals of different genotypes. However, some differences were observed for some traits in some genetic groups. In $1 / 2$ Dorper, the BB animals presented lower AFL $(p<0.05)$. In the Santa Inês breed, animals with this same genotype also presented lower LI. For the maternal trait LWW, AB animals weaned heavier litters.

Table 3 presents the averages of traits measured in the lambs of genotyped ewes. Lambs of BB 1/2 Dorper ewes presented lower averages for BW, WW and GBW, while lambs of BB Santa Inês ewes presented lower averages only for WW.

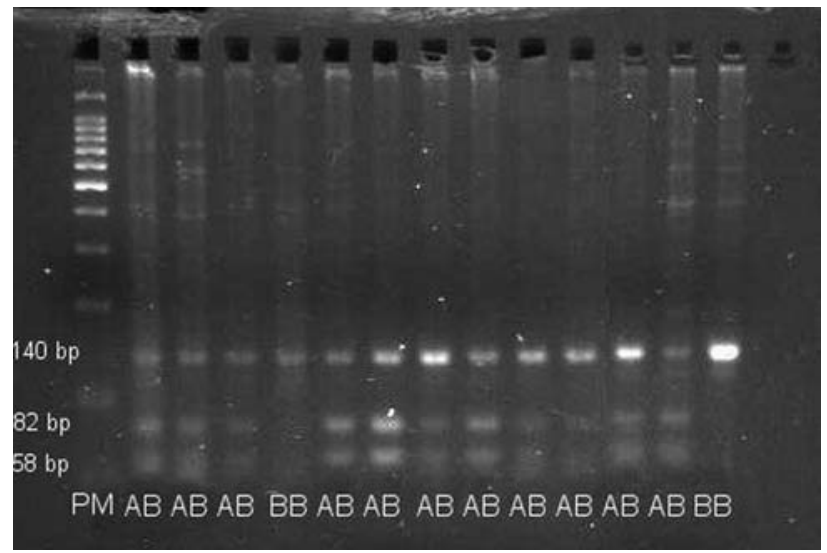

Figure 1 - Analysis of RFLP polymorphism of the aromatase gene (Cyp 19) in ovine. Non-digested PCR products are $140 \mathrm{bp}$ in size (allele B). In the case of allele A, there are two fragments of $82 \mathrm{bp}$ and $58 \mathrm{bp}$, respectively. $\mathrm{PM}=100 \mathrm{bp}$ Molecular Weight Ladder (Promega $\left.{ }^{\circledR}\right)$. AB and BB are the deduced genotypes.
Table 1 - Allelic frequencies of the breeds studied.

\begin{tabular}{lccc}
\hline Genetic group & $\begin{array}{c}\text { Number of } \\
\text { animals }\end{array}$ & $\begin{array}{c}\text { Frequency of } \\
\text { allele A }\end{array}$ & $\begin{array}{c}\text { Frequency of } \\
\text { allele B }\end{array}$ \\
\hline 1/2 Dorper & 18 & 0.194 & 0.806 \\
Poll Dorset & 9 & 0.390 & 0.610 \\
Santa Inês & 71 & 0.400 & 0.600 \\
Brazilian Somali & 13 & 0.000 & 1.000 \\
\hline
\end{tabular}

Table 4 presents the values of the likelihood ratio test (LR) for models including or not the effect of the aromatase gene in the analysis for estimating the breeding values of the studied traits. For all traits and models considered, the utilization of the aromatase genotype effect was important. The inclusion of the genotype information allowed a better fitting of the analyses of the measured traits, both in the genotyped animal itself and in the lambs of genotyped ewes. A significant decrease $(p<0.01)$ in $-2 \log L$ was found when the genotype information was included.

The comparison between the averages of breeding values estimated for growth, reproductive and maternal traits, according to the two genotypes observed for the aromatase gene, is presented in Table 5. Considering the breeding values estimated in genotyped animal, except for weaning weight (maternal effect), weight gain from weaning to slaughter, weight gain from weaning to yearling, age at first lambing and gestation length, there were differences in the averages of breeding values.

Regarding growth traits, the animals with genotype $\mathrm{AB}$ presented, on average, higher breeding values than those with genotype BB. Similarly, the lambs of ewes with genotype $\mathrm{AB}$ presented higher breeding values than those of mothers with genotype BB, except for GWS.

With regard to reproductive traits, there were differences only in LI and LD. The animals with genotype $A B$ presented better breeding values for LI (lower) and worse breeding values for $\mathrm{LD}$ (higher). Ewes with genotype $\mathrm{AB}$ presented a higher maternal ability than those with genotype BB. Their values for LWB and LWW were superior by $0.099 \mathrm{~kg}$ and $0.319 \mathrm{~kg}$, respectively. This trend was confirmed in the analysis that considered the effect of the maternal genotype on the breeding values of their lambs. The expected progeny differences regarding $\mathrm{BW}, \mathrm{WW}$ and GBW were, respectively, $0.06 \mathrm{~kg}, 0.08 \mathrm{~kg}$ and $1.79 \mathrm{~g} /$ day higher for lambs of $\mathrm{AB}$ ewes than for lambs of $\mathrm{BB}$ ewes.

\section{Discussion}

Coincidently, all rams of the herd sampled in this work had genotype AB. There were no AA animals in the analyzed sample, probably due to the low frequency of allele A. Vanselow et al. (1999) studied purebred ovine animals from Europe and identified three genotypes, with a frequency of 0.74 for allele A and 0.26 for allele B in Hungarian Merino animals, and a frequency of 1.00 for allele $\mathrm{A}$ 
Table 2 - Least square means for traits measured in animals with genotypes AB and BB for the aromatase gene.

\begin{tabular}{|c|c|c|c|c|c|}
\hline \multirow[b]{2}{*}{ Trait } & \multirow[b]{2}{*}{ Genetic group } & \multicolumn{2}{|r|}{ Genotype $\mathrm{AB}$} & \multicolumn{2}{|r|}{ Genotype BB } \\
\hline & & $\mathrm{N}$ & Mean \pm standard error & $\mathrm{N}$ & Mean \pm standard error \\
\hline \multirow[t]{2}{*}{ BW (kg) } & 1/2 Dorper & 7 & $3.43 \pm 0.29$ & 11 & $2.86 \pm 0.32$ \\
\hline & Santa Inês & 44 & $3.69 \pm 0.45$ & 12 & $3.21 \pm 0.51$ \\
\hline \multirow[t]{2}{*}{ WW (kg) } & 1/2 Dorper & 7 & $12.75 \pm 2.11$ & 11 & $11.77 \pm 2.53$ \\
\hline & Santa Inês & 43 & $17.01 \pm 1.27$ & 11 & $16.38 \pm 1.41$ \\
\hline YW (kg) & Santa Inês & 16 & $36.25 \pm 2.51$ & 5 & $42.00 \pm 2.73$ \\
\hline \multirow[t]{2}{*}{ GBW (kg) } & 1/2 Dorper & 7 & $0.190 \pm 0.038$ & 11 & $0.184 \pm 0.046$ \\
\hline & Santa Inês & 42 & $0.231 \pm 0.021$ & 11 & $0.224 \pm 0.024$ \\
\hline GWY (kg) & Santa Inês & 15 & $0.069 \pm 0.008$ & 4 & $0.084 \pm 0.009$ \\
\hline \multirow[t]{2}{*}{ AFL (day) } & 1/2 Dorper & 5 & $549.42 \pm 26.12^{\mathrm{a}}$ & 8 & $361.84 \pm 37.52^{\mathrm{b}}$ \\
\hline & Santa Inês & 18 & $526.44 \pm 23.64$ & 9 & $556.17 \pm 23.46$ \\
\hline \multirow[t]{2}{*}{ LI (day) } & 1/2 Dorper & 6 & $231.95 \pm 13.60$ & 9 & $221.73 \pm 9.42$ \\
\hline & Santa Inês & 58 & $246.48 \pm 15.07^{\mathrm{a}}$ & 9 & $218.75 \pm 19.01^{\mathrm{b}}$ \\
\hline LD (day) & Santa Inês & 18 & $162.43 \pm 6.13$ & 3 & $178.89 \pm 10.52$ \\
\hline \multirow[t]{2}{*}{ GL (day) } & 1/2 Dorper & 11 & $149.30 \pm 0.96$ & 17 & $148.03 \pm 1.02$ \\
\hline & Santa Inês & 77 & $150.87 \pm 0.88$ & 19 & $149.82 \pm 1.19$ \\
\hline \multirow[t]{2}{*}{ LWB (kg) } & 1/2 Dorper & 11 & $5.44 \pm 0.32$ & 17 & $5.38 \pm 0.34$ \\
\hline & Santa Inês & 77 & $5.96 \pm 0.20$ & 19 & $5.94 \pm 0.27$ \\
\hline \multirow[t]{2}{*}{ LWW (kg) } & 1/2 Dorper & 6 & $24.96 \pm 1.31^{\mathrm{a}}$ & 14 & $19.88 \pm 1.40^{\mathrm{b}}$ \\
\hline & Santa Inês & 56 & $20.15 \pm 0.93^{\mathrm{a}}$ & 13 & $17.89 \pm 1.32^{\mathrm{b}}$ \\
\hline
\end{tabular}

${ }^{\mathrm{a}, \mathrm{b}}$ Means with different superscripts are statistically different $(\mathrm{p}<0.05 ; t$ test $)$; BW $=$ birth weight, $\mathrm{WW}=$ weaning weight, $\mathrm{YW}=\mathrm{yearling}$ weight, $\mathrm{GBW}=$ weight gain from birth to weaning, GWY = weight gain from weaning to yearling, $\mathrm{AFL}=$ age at first lambing, $\mathrm{LI}=$ lambing interval, $\mathrm{GL}=$ gestation length, $\mathrm{LD}=$ lambing date, $\mathrm{LWB}=$ litter weight at birth, $\mathrm{LWW}=$ litter weight at weaning; $\mathrm{N}=$ number of observations.

Table 3 - Least square means for traits measured in lambs of ewes genotyped for the aromatase gene.

\begin{tabular}{|c|c|c|c|c|c|}
\hline \multirow[b]{2}{*}{ Trait } & \multirow[b]{2}{*}{ Genetic group } & \multicolumn{2}{|r|}{ Genotype AB } & \multicolumn{2}{|r|}{ Genotype BB } \\
\hline & & $\mathrm{N}$ & Mean \pm standard error & $\mathrm{N}$ & Mean \pm standard error \\
\hline \multirow[t]{4}{*}{ BW (kg) } & 1/2 Dorper & 17 & $4.25 \pm 0.21^{\mathrm{a}}$ & 38 & $3.22 \pm 0.13^{\mathrm{b}}$ \\
\hline & 1/2 Santa Inês & 1 & $3.82 \pm 0.69$ & 28 & $3.36 \pm 0.17$ \\
\hline & 3/4 Dorper & 17 & $3.41 \pm 0.26$ & 14 & $3.34 \pm 0.27$ \\
\hline & Santa Inês & 126 & $3.89 \pm 0.10$ & 22 & $3.61 \pm 0.17$ \\
\hline \multirow[t]{4}{*}{ WW (kg) } & 1/2 Dorper & 12 & $16.93 \pm 0.69^{\mathrm{a}}$ & 30 & $14.42 \pm 0.47^{\mathrm{b}}$ \\
\hline & 1/2 Santa Inês & 1 & $14.59 \pm 5.02$ & 22 & $13.04 \pm 1.37$ \\
\hline & 3/4 Dorper & 8 & $16.51 \pm 1.51$ & 11 & $13.09 \pm 1.62$ \\
\hline & Santa Inês & 91 & $15.54 \pm 0.41^{\mathrm{a}}$ & 16 & $13.86 \pm 0.81^{\mathrm{b}}$ \\
\hline SW (kg) & Santa Inês & 11 & $30.54 \pm 1.17$ & 2 & $32.74 \pm 2.39$ \\
\hline YW (kg) & Santa Inês & 12 & $36.54 \pm 4.01$ & 4 & $37.91 \pm 8.14$ \\
\hline \multirow[t]{4}{*}{ GBW (kg) } & 1/2 Dorper & 12 & $0.264 \pm 0.012^{\mathrm{a}}$ & 30 & $0.224 \pm 0.008^{b}$ \\
\hline & 1/2 Santa Inês & 1 & $0.191 \pm 0.092$ & 22 & $0.190 \pm 0.021$ \\
\hline & 3/4 Dorper & 8 & $0.274 \pm 0.033$ & 11 & $0.198 \pm 0.035$ \\
\hline & Santa Inês & 91 & $0.236 \pm 0.009$ & 16 & $0.211 \pm 0.017$ \\
\hline GWS (kg) & Santa Inês & 11 & $0.202 \pm 0.010$ & 2 & $0.240 \pm 0.020$ \\
\hline GWY (kg) & Santa Inês & 10 & $0.056 \pm 0.009$ & 4 & $0.053 \pm 0.016$ \\
\hline
\end{tabular}

\footnotetext{
${ }^{\mathrm{a}, \mathrm{b}}$ Means with different superscripts are statistically different $(\mathrm{p}<0.05 ; t$ test $)$; $\mathrm{BW}=$ birth weight, $\mathrm{WW}=$ weaning weight, $\mathrm{SW}=$ slaughter weight, $\mathrm{YW}=$ yearling weight, GBW = weight gain from birth to weaning, GWS = weight gain from weaning to slaughter, GWY = weight gain from weaning to yearling; $\mathrm{N}=$ number of observations.
} 
Table 4 - Logarithm values of the likelihood function $(-2 \log \mathrm{L})$ and values for likelihood rate (LR) test for the studied traits, according to the respective model.

\begin{tabular}{lccc}
\hline $\begin{array}{l}\text { Model/trait mea- } \\
\text { sured in genotyped } \\
\text { animal }\end{array}$ & $\begin{array}{c}\text { Without geno- } \\
\text { type effect } \\
-2 \text { Log L }\end{array}$ & $\begin{array}{c}\text { With genotype } \\
\text { effect } \\
-2 \text { Log L }\end{array}$ & -2 Log LR \\
\hline BW, WW and YW & 208.8689 & 175.4608 & $33.41^{* *}$ \\
GBW and GWY & 389.1728 & 327.0870 & $62.08^{* *}$ \\
AFL, LI and GL & 446.9582 & 410.3368 & $36.62^{* *}$ \\
LD & 62.7478 & 54.9946 & $7.75^{* *}$ \\
LWB and LWW & 148.2612 & 128.5329 & $19.72^{* *}$ \\
\hline Model/trait mea- & Without mater- & With maternal & -2 Log LR \\
sured in lambs of & nal genotype & genotype effect & \\
genotyped ewes & effect -2 Log L & -2 Log L & \\
\hline BW, WW and SW & 543.1798 & 510.7648 & $32.41^{* *}$ \\
BW, WW and YW & 540.6258 & 506.3233 & $34.30^{* *}$ \\
GBW and GWS & 1247.8714 & 1173.4227 & $74.45^{* *}$ \\
GBW and GWY & 1209.9369 & 1142.5747 & $67.36^{* *}$ \\
\hline
\end{tabular}

${ }^{* *} \mathrm{p}<0.01 ; \mathrm{BW}=$ birth weight; $\mathrm{WW}=$ weaning weight; $\mathrm{SW}=$ slaughter weight; $\mathrm{YW}=$ yearling weight; $\mathrm{GBW}=$ weight gain from birth to weaning; GWS = weight gain from weaning to slaughter; GWY = weight gain from weaning to yearling; $\mathrm{AFL}=$ age at first lambing; $\mathrm{LI}=$ lambing interval; $\mathrm{GL}=$ gestation length; $\mathrm{LD}=$ lambing date; $\mathrm{LWB}=$ litter weight at birth; $\mathrm{LWW}=$ litter weight at weaning.

(none for allele B) in Lacaune animals. To our best knowledge, besides the study of Vanselow et al. (1999), there is no other report in the literature on aromatase gene frequencies in ovine. In all animals sampled, except Brazilian Somali, polymorphism for the aromatase gene was observed.

High aromatase activity in trophoblast of preimplantation pig embryos is associated with maternal recognition of pregnancy and the occurrence of superficial implantation in pigs, sheep, cows, roe deer, ferrets, cats, rabbits and a plains viscacha (Gadsby et al., 1980).

In male mice, Wang et al. (2001) observed that elevated Cyp 19 expression was followed by an increase in the intratesticular levels of estradiol. These authors concluded that aromatase seems to be a physiological target of Dax-1 (an orphan nuclear receptor that represses transcription by steroidogenic factor-1, SF-1) in Leydig cells, and increased Cyp19 expression may account, in part, for infertility and Leydig cell hyperplasia (LCH) in Daxl-deficient mice.

Gestagens and estrogens are important regulators of pregnancy and parturition. Vanselow et al. (2004) reported that in cattle and sheep Cyp19 transcripts were found at high concentrations in the placenta and at a very low concentration in the corpus luteum. According to Luo and Wiltbank (2006), in bovine, Cyp19A1 (aromatase) is regulated by multiple pathways, including estrogen receptors and cAMP/protein kinase A induced by FSH hormone activation in granulosa cells. These inter and intracellular regulatory mechanisms may be critical for normal follicle growth and dominant follicle selection.
Table 5 - Comparison between averages of breeding values estimated for growth, reproductive and maternal traits of a multibreed population of sheep, according to the genotype for the aromatase gene.

\begin{tabular}{lcc}
\hline & \multicolumn{2}{c}{ Genotypes } \\
\cline { 2 - 3 } Trait & $\mathrm{AB}$ & $\mathrm{BB}$ \\
\hline Breeding values estimated in genotyped animal & & \\
Birth weight - direct effect $(\mathrm{kg})$ & $0.205^{\mathrm{a}}$ & $0.003^{\mathrm{b}}$ \\
Birth weight - maternal effect $(\mathrm{kg})$ & $0.015^{\mathrm{a}}$ & $-0.085^{\mathrm{b}}$ \\
Weaning weight - direct effect $(\mathrm{kg})$ & $0.722^{\mathrm{a}}$ & $-0.048^{\mathrm{b}}$ \\
Weaning weight - maternal effect $(\mathrm{kg})$ & $-0.072^{\mathrm{a}}$ & $-0.237^{\mathrm{a}}$ \\
Yearling weight (kg) & $1.060^{\mathrm{a}}$ & $-0.754^{\mathrm{b}}$ \\
Slaughter weight (kg) & $1.000^{\mathrm{a}}$ & $-0.778^{\mathrm{b}}$ \\
Weight gain from birth to weaning - direct effect & $8.182^{\mathrm{a}}$ & $2.907^{\mathrm{b}}$ \\
(g/day) & & \\
Weight gain from birth to weaning - maternal & $1.887^{\mathrm{a}}$ & $-4.043^{\mathrm{b}}$ \\
effect (g/day) & & \\
Weight gain from weaning to slaughter (g/day) & $-3.335^{\mathrm{a}}$ & $-2.505^{\mathrm{a}}$ \\
Weight gain from weaning to yearling (g/day) & $1.685^{\mathrm{a}}$ & $0.422^{\mathrm{a}}$ \\
Age at first lambing (day) & $1.605^{\mathrm{a}}$ & $1.375^{\mathrm{a}}$ \\
Lambing interval (day) & $-5.653^{\mathrm{a}}$ & $-3.673^{\mathrm{b}}$ \\
Lambing date (day) & $0.2790^{\mathrm{a}}$ & $0.0646^{\mathrm{b}}$ \\
Gestation length (day) & $-0.0825^{\mathrm{a}}$ & $-0.0934^{\mathrm{a}}$ \\
Litter weight at birth (kg) & $0.128^{\mathrm{a}}$ & $0.029^{\mathrm{b}}$ \\
Litter weight at weaning (kg) & $0.282^{\mathrm{a}}$ & $-0.037^{\mathrm{b}}$ \\
\hline
\end{tabular}

Breeding values estimated in lambs of genotyped ewes

\begin{tabular}{|c|c|c|}
\hline Birth weight - direct effect $(\mathrm{kg})$ & $0.190^{\mathrm{a}}$ & $-0.030^{\mathrm{b}}$ \\
\hline Birth weight - maternal effect (kg) & $0.034^{\mathrm{a}}$ & $-0.082^{b}$ \\
\hline Weaning weight - direct effect $(\mathrm{kg})$ & $0.745^{\mathrm{a}}$ & $-0.027^{\mathrm{b}}$ \\
\hline Weaning weight - maternal effect $(\mathrm{kg})$ & $-0.025^{\mathrm{a}}$ & $-0.185^{\mathrm{b}}$ \\
\hline Yearling weight $(\mathrm{kg})$ & $1.181^{\mathrm{a}}$ & $-0.704^{b}$ \\
\hline Slaughter weight (kg) & $1.043^{\mathrm{a}}$ & $-0.539^{b}$ \\
\hline $\begin{array}{l}\text { Weight gain from birth to weaning - direct effect } \\
\text { (g/day) }\end{array}$ & $9.670^{\mathrm{a}}$ & $4.722^{\mathrm{b}}$ \\
\hline $\begin{array}{l}\text { Weight gain from birth to weaning - maternal } \\
\text { effect ( } g \text { /day) }\end{array}$ & $1.750^{\mathrm{a}}$ & $-1.828^{\mathrm{b}}$ \\
\hline Weight gain from weaning to slaughter (g/day) & $-2.986^{\mathrm{b}}$ & $0.619^{\mathrm{a}}$ \\
\hline Weight gain from weaning to yearling ( $\mathrm{g} /$ day) & $2.129^{\mathrm{a}}$ & $0.687^{\mathrm{b}}$ \\
\hline
\end{tabular}

Same letters in same row indicate that there is no statistical difference $(\mathrm{p}>0.05 ; t$ test $)$.

All these pieces of evidence allow concluding that the polymorphism produces differences in aromatase activity, justifying the differences observed in reproductive performance (AFL and LI) and in maternal ability (LWW) of some genetic groups studied here. Aromatase inhibition rapidly decreases both appetitive and consummatory aspects of male sexual behavior (Cornil et al., 2006; Roselli et al., 2006). Therefore, such enzyme activity differences among animals could produce a difference in AFL and in LI. On the other hand, it is known that traits measured until weaning are subject to strong maternal influence. Thus, our 
analyses of weight and weight gains until weaning corroborate the findings for $\mathrm{LWW}$, i.e., that $\mathrm{AB}$ aromatase gene ewes tend to present greater maternal ability. However, in Black-and-White and Jersey cattle, Jedrzejczak et al. (2006) did not observe any association between the CYP19-PvuII polymorphism and milk production traits.

The better fitting of models with the inclusion of the aromatase gene genotype suggests that whenever information about the animal genotype is available should be included in the models for estimating genetic parameters and breeding values. It is important to point out that the small number of genotyped animals in this study did not permit greater considerations about the estimated parameters. However, the inclusion of the genotype was important for the comparative analysis. Thus, as a larger number of genotyped animals becomese available from future studies, this information can and should be included in the analysis models for estimates of quantitative breeding values.

Overall, differences among breeding values were observed according to the genotype for the aromatase gene. Using this information could improve the breeding values estimates. The use of the animal's genotype or of the genotype of its mother in the analysis will depend on the amount of available information or of the trait itself. We suggest that traits under larger maternal influence should be analyzed using the information of the mother's genotype. On the other hand, traits that are more subject to the effect of the individual's genes should be evaluated by including the information of this individual's genotype. It is also worth pointing out that the use of the mother's genotype multiplies the data available for analysis, once a ewe has several lambs, and this information can be used in the analyses of the traits of these lambs.

In this study, the genotype was included as fixed effect, so in future investigations other analyses could be made, as suggested by Muir (2007), combining mixed models utilizing a second random genetic effect for genotype, once there is sufficient recorded information on genotype and phenotype.

The heterozygotes for the aromatase gene showed, on average, better breeding values than the BB homozygotes. The estimated breeding values are due to additive genetic action. However, as in this population there is a participation of many breeds and their crossbreeding, it is possible that non-additive genetic effects were present in these estimates. The combination of breeds promotes higher heterosis, due to the increase of heterozygosis in the population. This could explain the superiority of heterozygote animals.

The results of this study point to a so far not elucidated difference among sheep with different genotypes for the aromatase gene. Future investigations may reveal whether this polymorphism is responsible for differences in the performance of animals and thus help in the selection of superior animals.

\section{Acknowledgments}

Financial support was provided by Conselho Nacional de Desenvolvimento Científico e Tecnológico (CNPq) and Embrapa Caprinos e Ovinos.

\section{References}

Boldman KG, Kriese LA, Van Vleck DL, Van Tassell CP and Kachman SD (1995) A Manual for Use of MTDFREML. A set of programs to obtain estimates of variances and covariances [Draft]. USDA/Agricultural Research Service, Lincoln, $120 \mathrm{pp}$.

Carani C, Qin K, Simoni M, Faustini-Fustini M, Serpente S, Boyd J, Korach KS and Simpson ER (1997) Effect of testosterone and estradiol in a man with aromatase deficiency. N Engl J Med 337:91-95.

Conley AJ and Hinshelwood M (2001) Mammalian aromatases. Reproduction 121:685-695.

Cornil CA, Taziaux M, Baillien M, Ball GF and Balthazart J (2006) Rapid effects of aromatase inhibition on male reproductive behaviors im japanese quail. Horm Behav 49:45-67.

Gadsby JE, Heap RB and Burton RD (1980) Oestrogen production by blastocyst and early embryonic tissue of various species. J Reprod Fertil 60:409-17.

Goldammer T, Brunner RM, Vanselow J, Zsolnai A, Fürbass R and Schwerin M (1999) Assignment of the bovine aromatase encoding gene CYP19 to 10q26 in goat and 7q24-q31 in sheep. Cytogenet Cell Genet 85:258-259.

Heine PA, Taylor JA, Iwamoto GA, Lubahn DB and Cooke PS (2000) Increased adipose tissue in male and female estrogen receptor-alpha knockout mice. Proc Natl Acad Sci USA 97:12729-12734.

Hoffmann B, Wagner WC, Hixon JE and Bahr J (1979) Observations concerning the functional status of the corpus luteum and the placenta around parturition in the cow. Anim Reprod Sci 2:253-266.

Jedrzejczak M, Szatkowska I, Zych S, Grzesiak W, Czerniawska-Piatkowska E and Dybusi A (2006) Evaluation of associations of the polymorphism in the placenta-specific promoter 1.1 of the CYP19 gene in Black-and-White and Jersey cattle with milk production traits. Arch Tierz Dummerstorf 49:311-314.

Jones ME, Thorburn AW, Britt KL, Hewitt KN, Wreford NG, Proietto J, Oz OK, Leury BJ, Robertson KM, Yao S, et al. (2000) Aromatase-deficient (ArKO) mice have a phenotype of increased adiposity. Proc Natl Acad Sci USA 97:1273512740.

Luo W and Wiltbank MC (2006) Distinct regulation by steroids of mssenger RNAs for FSHR and CYP19A1 in bovine granulosa cells. Biol Reprod 75:217-225.

Miller SA, Dykes DD and Polesky HF (1988) A simple salting out procedure for extracting DNA from human nucleated cells. Nucleic Acids Res 16:1215.

Morishima A, Grumbach MM, Simpson ER, Fisher C and Qin K (1995) Aromatase deficiency in male and female siblings caused by a novel mutation and the physiological role of estrogens. J Clin Endocrinol Metab 80:3689-98.

Muir MW (2007) Comparison of genomic and traditional BLUPestimated breeding value accuracy and selection response 
under alternative trait and genomic parameters. J Anim Breed Genet 124:342-355.

Payen E, Saidi-Mehtar N, Pailhoux E and Cotinot C (1995) Sheep gene mapping: Assignment of ALDOB, CYP19, WT and SOX2 by somatic cell hybrid analysis. Anim Genet 26:331333.

Rao CR (1973) Minimum variance quadratic unbiased estimation of variance components. J Mult Anal 1:445-452.

Roselli CE, Schrunk JM, Stadelman HL, Resko JA and Stormshak F (2006) The effect of aromatase inhibition on the sexual differentiation of the sheep brain. Endocrine 29:501-511.

SAS Institute Inc (1996) SAS/STAT. User's Guide,v. 6.11. $4^{\text {th }}$ ed., v.2. SAS Institute Inc., Cary, 842 pp.

Simpson E, Rubin G, Clyne C, Robertson K, O’Donnell L, Jones $M$ and Davis S (2000) The role of local estrogen biosynthesis in males and females. Trends Endocrinol Metab 11:184-188.

Simpson ER, Mahendroo MS, Means GD, Kilgore MW, Hinshelwood MM, Graham-Lorence S, Amarneh B, Yuji I, Fisher CR, Michael MD, et al. (1994) Aromatase cytochrome $\mathrm{P} 450$, the enzyme responsible for estrogen biosynthesis. Endocr Rev 15:342-355.

Thorburn GD and Challis JR (1979) Endocrine control of parturition. Physiol Rev 59:863-918.
Vanselow J, Zsolnai A, Fésus L, Schmidt P and Schwerin MA (1999) Bsp 143I PCR-RFLP in exon 3 of the ovine aromatase gene (CYP19). Anim Genet 30:382-405.

Vanselow J, Fürbass R, Zsolnai A, Kalbe C, Said HM and Schwerin M (2001) Expression of the aromatase cytochrome P450 encoding gene in cattle and sheep. J Steroid Biochem Mol Biol 79:279-288.

Vanselow J, Fürbass R, Rehbock F, Klautschek G and Schwerin $\mathrm{M}$ (2004) Cattle and sheep use different promoters to direct the expression of the aromatase cytochrome P450 encoding gene, Cyp 19, during pregnancy. Domest Anim Endocrin 27:99-114.

Wang ZJ, Jeffs B, Ito M, Achermann JC, Yu RN, Hales DB and Jameson JL (2001) Aromatase (Cyp19) expression is upregulated by targeted disruption of Dax1.Proc Natl Acad Sci USA 98:7988-7993.

Wendorf GL, Lawyer MS and First NL (1983) Role of the adrenals in the maintenance of pregnancy in cows. J Reprod Fertil 68:281-287.

Associate Editor: Pedro Franklin Barbosa

License information: This is an open-access article distributed under the terms of the Creative Commons Attribution License, which permits unrestricted use, distribution, and reproduction in any medium, provided the original work is properly cited. 